\title{
原著
}

\section{透析液調製作業の人間工学的検討 一原液型とドライ型において一}

\author{
吉村勲友田泰行田中寛 \\ 関西大学工学部管理工学科 大野記念病院泌尿器科*
}

key words：血液透析，透析液調製，濃縮液型透析液，ドライケミカル型透析液，人間工学

〈要旨〉

糖加重炭酸型透析液の 2 剤濃縮液型（原液型）と 2 剤ドライ型（ドライ型，自動溶解希釈装置を使用）との 2 種類 の薬剤を用いた時の透析液作業（運搬，透析液調製，空容器搬出）を，人間工学的に比較検討した。対象は 1 日に原 液使用量 55 セットを使用する腎臓病センター（透析用ベッド 93 床, 透析患者 280 例）で働く臨床工学技士 5 名とし た。

ドライ型の使用量は原液型に比し重量で $1 / 6.7$, 容積で $1 / 3.5$ であった. 臨床工学技士の一日の作業時間を $100 \%$ と した時の実作業時間は $85.9 \%$ であり，そのうち透析液作業時間は原液型 $23.1 \%$ ，ドライ型 $6.0 \%$ あっあた。乥して， その時の運搬移動距離でも原液型 $928 \mathrm{~m}$, ドライ型 $263 \mathrm{~m}$ とドライ型の優位点が示された。身体への負荷に関する 比較では, 透析液作業中の 8 工程で, 原液型での心拍数がドライ型での光れに比し有意に高値であった。 以上より, 原液型での透析医療作業の阻害の程度が明らかとなり,ドライ型によるそれらの軽減効果が期待された。

An ergonomic study on the work involved in preparing dialysate-comparison between concentrated liquid and dry chemical types of bicarbonatebuffered dialysate-

Isao Yoshimura, Yasuyuki Tomoda, Hiroshi Tanaka*

Faculty of Engineering, Kansai University and Department of Urology, Ohno Memorial Hospital*

We used ergonomic procedures to measure the work of 5 male hemodialysis technicians in preparing and transporting bicarbonate buffered dialysate, and compared the work time, distance and work load when they prepared concentrated liquid (hereafter referred to as LIQUID, Kindary AF-2, Fuso Pharmaceutical Co., Ltd., Osaka, Japan) and dry chemicals (hereafter as DRY, AKDD, Towa Pharmaceutical Co., Ltd., Kadoma, Japan, with an automatic dissolving and diluting system, Nikkiso Co., Ltd., Tokyo, Japan) at the Kidney Disease Medical Center, Ohno Memorial Hospital, where there are 93 patient stations and 280 hemodialysis patients, consuming 55 sets of LIQUID daily. When LIQUID and DRY were compared quantitatively for the two daily shifts of hemodialysis treatments, DRY was $1 / 6.7$ of the weight of LIQUID and $1 / 3.5$ of its volume. The trolley used in the hospital could carry 80 sets of DRY and 20 sets of LIQUID. The work required $23.1 \%$ of technician's daily work time for the LIQUID (7.8\% for transportation and $15.3 \%$ for preparation) and $6.0 \%$ for the DRY (1.8\% for transportation and $4.2 \%$ for preparation). The distance traveled for transportation of the DRY in the hospital and the technician's laboratory was $28.3 \%$ of the distance required for the LIQUID. The work load caused the technicians' mean heart rate to increase significantly with the LIQUID, but it did not change with the DRY.

In conclusion, DRY dramatically reduced the work of providing dialysate in a clinical facility and improved the quiality of the work life (QWL) of the hemodialysis technicians.

吉村 勲 関西大学工学部 ₹ 564 吹田市山手町 3-3-35 (06-368-0975)

〔受付：平成 6 年 4 月 13 日, 受理 : 平成 6 年 7 月 25 日〕 


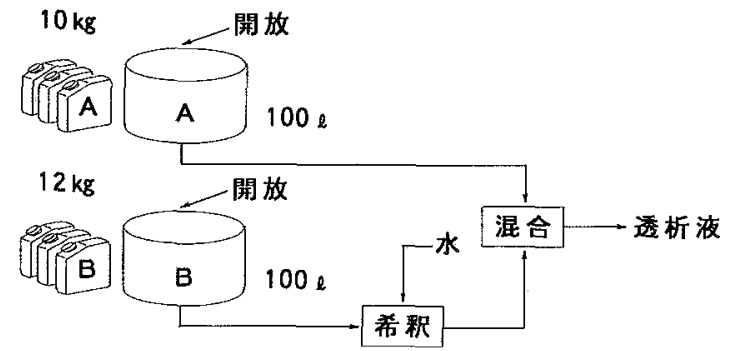

マニュアル開封，注入

原液型

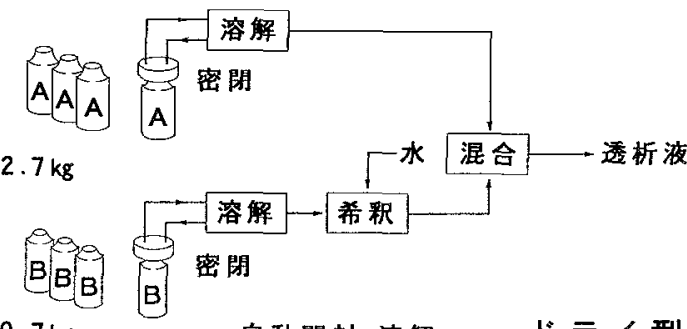

$0.7 \mathrm{~kg}$

自動開封 , 溶解

ドライ型

図 1 原液調製システム

\section{緒言}

透析液作製のための作業には透析原液の運搬・開封・ 開栓・注入・空容器の片付け・搬出などがあり，我々は この業務全体を透析液作業と呼んでいる1.これらの作 業は看護婦と同様に行う透析室内の業務とは異なり，精 神的・肉体的に過酷であり，昨今の製造業の中でも，ほ とんど見かけなくなった作業動作である。しかしながら， 現在のところは 2 剂濃縮型透析原液（原液型）が依然使 用されている。今回，2剤ドライケミカル型透析液粉末 郕（ドライ型）と，その自動溶解希釈装置を使用する機 会を得たので，両楽剤使用時の透析液作業量を人間工学 的に比較・検討した。

\section{対象}

対象を大野記念病院腎臟病センターで働く5名の男子 臨床工学技士（年齢 $30.6 \pm 2.2$ 歳）とした。同腎臟病セ ンターには透析用ベッドサイドモニターが 93 台あり, 対 象の他には看護婦 35 名, 看護助手 5 名が働いていた。透 析患者数は 280 例で，通常一日に使用する透析液（原液 型）は 55 セットであり，薬剈の搬入場所（1階）から調 製室（3 階）までの距離が $55 \mathrm{~m}$, 通路幅が $2.0 \mathrm{~m}$, 調製 室の広さは $80 \mathrm{~m}^{2}$ であった。

\section{方法}

本研究に際し，糖加重炭酸型透析液の原液型として 2 郕濃縮型透析原液キンダリー AF-2 (扶桑薬品, 大阪) を，ドライ型として 2 郕ドライケミカル型透析液粉末剤 AKDD (東和楽品, 門真) ${ }^{2 \sim 4)}$ を用いた。

原液型での透析液作業を以下に示す。薬剤の院内への
表 透析原液の剤型別の容積と重量

\begin{tabular}{|c|c|c|c|}
\hline \multicolumn{2}{|c|}{ 透析原液の剤型 } & 原液型 & ドライ型 \\
\hline \multicolumn{2}{|c|}{ 包装単位セット } & 1 & 4 \\
\hline \multicolumn{2}{|c|}{ 外箱外寸 $\mathrm{D} \times \mathrm{W} \times \mathrm{H}(\mathrm{cm})$} & $28 \times 35 \times 36$ & $33 \times 37 \times 34$ \\
\hline \multirow{2}{*}{ 容積 } & 1 箱 $\quad(\mathrm{L})$ & 34 & 39 \\
\hline & 1 セット（L） & 34 & 9.8 \\
\hline \multirow{2}{*}{ 重量 } & 1 箱 $\quad(\mathrm{kg})$ & 25 & 15 \\
\hline & 1 セット (kg) & 25 & 3.75 \\
\hline \multicolumn{2}{|c|}{ 一台車積載数量（セット） } & 20 & 80 \\
\hline 同 & 重量 (kg) & 500 & 300 \\
\hline
\end{tabular}

搬入場所（1 階）より対象が台車を利用して 3 階の腎臓 病センター横の調製室へ搬入した原液を, 開封仕分け (A，B）した後, 各原液ポリタンク $(12 \mathrm{~kg})$ の直径 $6 \mathrm{~cm}$ の主栓と $3 \mathrm{~cm}$ の空気拔き栓をスパナを用いて開栓し, 手で持ち上げ，それぞれのオープンタンクに注入した。

ドライ型では，搬入・開封後，ドライ型の規格にあわ せて開発された，全自動溶解希釈装置5) (日機装，東京） に顆粒カートリッジ $(A ， B) を 1$ 回に 11 セットずつ装 着した。

空容器の処理は両型とも空箱へ入れて搬出した。なお， 両剤の透析液調製システムを図 1 に示寸。

上記の作業を観察，分析するために，原液型を用いた ときの対象の一日の全作業とドライ型を用いたときの透 析液作業を VTR (video tape recorder) により録画し た。その後，各作業の画像を再生し，作業距離，時間を 測定し，作業動作分析，工程分析（ストリング・ダイヤ グラム分析を含む）を行った。同時に，作業中の身体へ の負荷の程度を推定するため，ホルター心電計を対象に 装着させ, 各工程別に平均心拍数の変化を観察した。な お，VTR 使用時には対象の被撮影者意識を除外するた め，あらかじめ 3 日間の空撮影を行った。

\section{結果}

同腎臟病センターで使用した原液型と同等量の透析液 を調製するためには，表に示すように一台車当たりの運 搬セット数量はドライ型は 80 セットで原液型の 20 セッ トより 60 セット多いが, 総重量で $200 \mathrm{~kg}$ も軽く, 原液 型の重量にして $1 / 6.7$, 容量にして $1 / 3.5$ であった。その 上，原液型では週に 3 回の搬送が必要であるが，ドライ 型では週に 1 回の搬送ですみ，ドライ型の作業性の良さ が認められた。

原液型使用時の対象の一日の，ならびにドライ型使用 時の透析液作業についての稼働分析を図 2 に示す。一日 8 時間の勤務時間を $100 \%$ とした時，休唕等非作業や余 


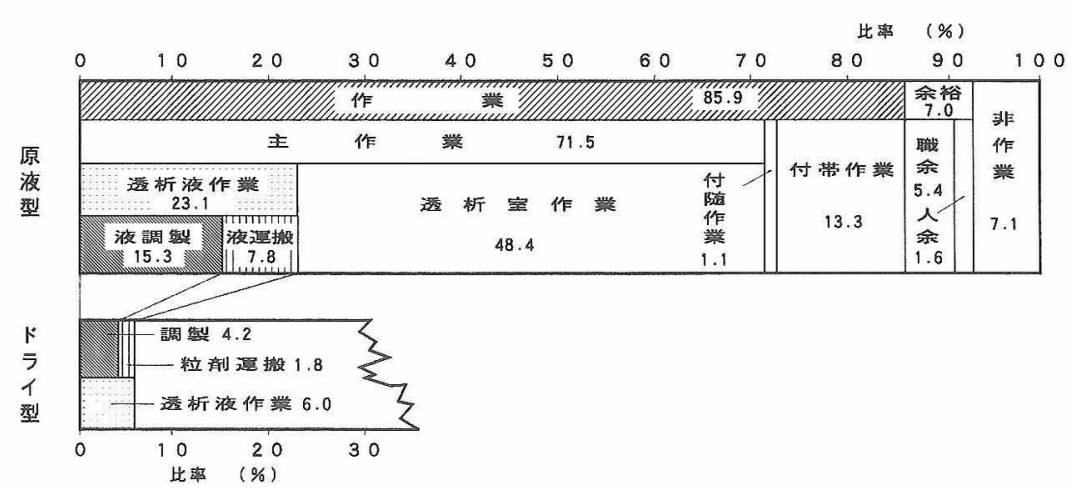

図 2 稼働分析の各作業比率

裕時間を除外した実作業時間は $85.9 \%$ であった。そのう ち原液型での透析液作業比率 $15.3 \%$ ，液運搬作業 $7.8 \%$ ，計 $23.1 \%$ でったが，ドラ 亿型では液調製作業 $4.2 \%$ ，粒剤運搬作業 $1.8 \%$ ，計 $6.0 \%$ と原液型の $1 / 3.9$ の作業時間であった。

両剂の搬入から空容器搬出までの作業点および動線を ストリング・ダイヤグラムに集約化し，工程別での 1 セッ 卜当たりの作業時間と運搬移動距離を図 3 に示す。原液 型では作業時間で原液注入 $\mathrm{A}, \mathrm{B}$ が 25 秒/セットを超え， 他工程との作業時間の差が大きく，ラインバランス（各 作業時間のバランス）が悪くなっていた。運搬移動距離 は搬入場所から調製室までの薬剤運搬，調製室内での注 入後の空容器運搬，廃棄処分のための空容器運搬がそれ ぞれ 3.5, 2.8, $3.0 \mathrm{~m} /$ セットあり，レイアウトをはじめと した設計上の問題が認められた。ドライ型では，容器装 着 $(A, B)$ と空容器箱詰めの工程作業時間が 5 秒を超 え，他の工程時間よりやや長いが，ラインバランスは原 液型に比し十分に改善された。運搬移動距離では工程間 での差はほとんどみられず，ドライ型の運搬移動距離を 一日当たりの移動距離として算出すると $263 \mathrm{~m}$ となり， 原液型の $928 \mathrm{~m}$ から $28.3 \%$ に短縮された。

工程別平均心拍数は図 4 に示すように，原液型では運 搬作業時の方が透析液調製作業時に比して上昇してお り，なかでも運搬，調製室での積み下ろし，箱開封取り 出しの各作業時には $140 /$ 分を超え，極端に高かった。ド ライ型では各作業時の心拍数は安静時より高くなったも のの 8 工程で原液型に比し有意に低い心拍数であった。

\section{考察}

多人数用重曹透析装置の開発，透析液組成の研究，透 析膜の開発や研究など透析療法のめざましい進歩が認め られるなかで，透析液調製作業に関してはほとんど改善 されていない。我々は透析医療環境の改善による医療品 質の向上のため透析室における看護婦や臨床工学技士の
作丵暗間 (秒/セッ卜) $\begin{array}{lllllll}30 & 25 & 20 & 15 & 10 & 5 & 0\end{array}$
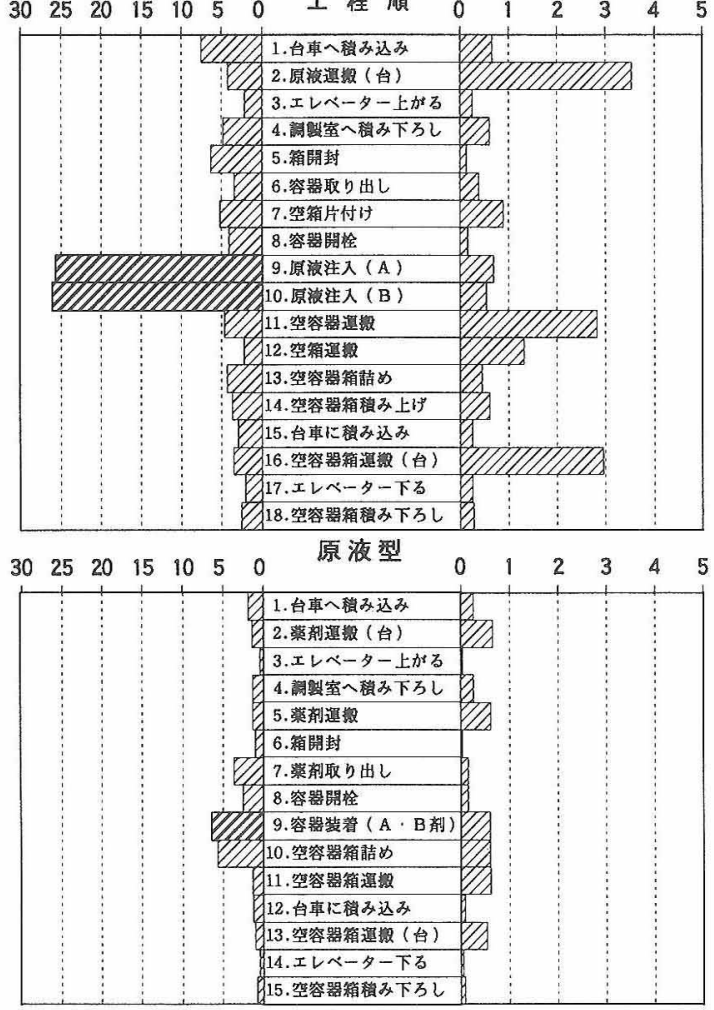

ドライ㤠

図 3 工程別所要時間と移動距離

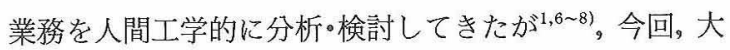
野記念病院腎臓病センターに括ける透析液の調製作業を 原液型とドライ型の透析液を用いて検討した。同腎臟病 センターで働く臨床工学技士らの勤務時間は実働 8 時 間/日（休咊時間を含む）であり，終日連続稼働観測によ り得られた実作業時間としての稼働率は平均 $85.9 \%$ と 


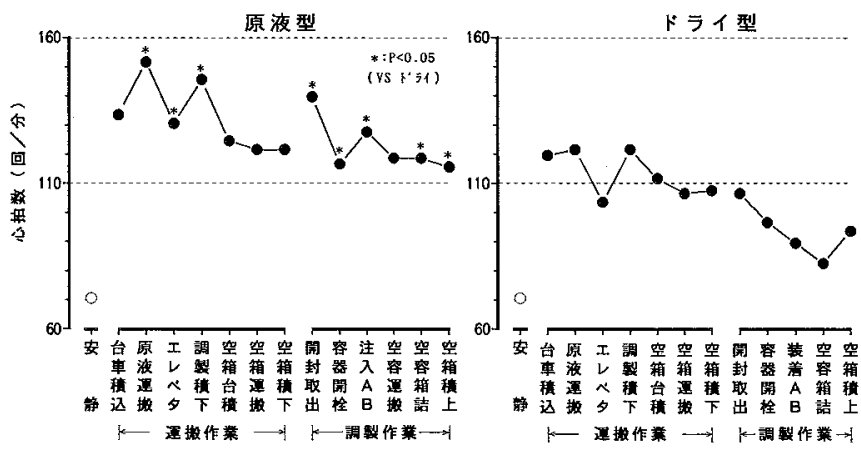

図 4 作業動作別平均心拍数

高率であり，問題のない稼働状況であった。しかし，原 液型での稼働状況は身体的な負荷の程度が強い透析液作 業と，精神面での負荷の程度が強い透析室内作業が混在 し, 透析液作業の稼働比率が,一日の勤務時間の約 $1 / 4$ を 占め, 妥当な作業環境のもとでの業務であるとは考えら れない．同腎臟病センターの場合には，原液型での透析 液作業は原液運搬のための動力台車の導入, 投入タンク の大型化，原液タンク保持具の工夫・取り付け，調製室 のレイアウトの変更などの改善により，透析液作業時間 の約 $20 \%$ 削減することができるが，全稼働時間の約 $5 \%$ 稼働率向上にしかならず，原液型を使用する限り においては，省力化にも限界がある1)。一方ドライ型で は, 表に示したように重量で $1 / 6.7$, 容量で約 $1 / 3.5$ とな り，原液型に比しその取扱いが容易となり，運搬作業回 数が削減され，作業点と動線の大幅な減少となるだけて なく，保管スペースや容器の廃棄処分についても有利と なる。また，透析液作業比率は $6.0 \%$ と原液型 (23.1\%) の $1 / 3.9$ となり，その省力された時間(一日当たり約 1.3 時間）を患者への透析室内作業に振り向けられることが 可能となる。

透析液調製作業時の工程別の心拍数の観察でも，原液 型で有意に高く，原液運搬時の心拍数はエレベータ内で 静態していても一向に低下しないほど強く，原液型の重 量と容積ならびに運搬量が大きく影響していることが示 された。ドライ型では透析液作業の身体的な負荷は軽微 となり，作業への就業の可能性が広がり，固定的作業者 でなくても透析液作業の担当が可能である。

その上，図 1 の原液調製システムで明らかなように， 原液型では $\mathrm{A} ・ \mathrm{~B}$ タンクが開放のままであり，特に B 液 の細菌繁殖によるエンドトキシンの饬染が懸念される。 ドライ型では全システムが密閉式で自動開封・溶解を行 うため，エンドトキシンの污染が原液型に比し少なく ${ }^{8)}$, ドライ型の医学的な優位点と考えられる。

今後, 臨床工学技士らのQWLの充実とともに，より
高い医療品質と医療業務体制維持のための手段として TQM (total quality management) ${ }^{9)}$ が必要であり, 省 力化だけでなく，スタッフの仕事の仕方や組織内部の人 間関係など，広く医療の場全体を視野に入れた組織文化 全体への対応が必要と考えられる。

\section{結論}

1.大野記念病院腎臓病センターが一日で使用する透 析液を 2 剤濃縮液型透析液（原液型）で調製する時に比 ベて，2剂ドライ型透析液（ドライ型，自動溶解希积装 置を使用)の場合には, その使用量は重量で $1 / 6.7$, 容積 で $1 / 3.5$ でった。

2. 原液型での臨床工学技士の透析液作業時間比率は 一日の勤務時間 8 時間の $23.1 \%$ あり，ドライ型では $6 \%$ 6 あった。

3. 透析液作業における院内運搬移動距離は，一日当 たり原液型 $928 \mathrm{~m}$ であったが，ドライ型は $263 \mathrm{~m}$ と $28.3 \%$ に短縮された。

4.自動溶解希釈装置を用いるドライ型は原液型に比 し，身体的負担が急減するだけでなく，その作業者特定 （身体的条件，技術能力）の必要性も認められなかった。

稿を終えるにあたり，貴重なご助言をいただいた東京女子 医科大学腎藏病総合医療センター所長太田和夫教授に深甚な る謝意を申し上げます。

\section{文献}

1）白神 徹, 南 伸治, 堀 昭, 中深典和, 藤島英 樹, 新田昌一, 竹垣嘉訓, 韓 榮新, 田中 寛, 大 野良興，前川正信，吉村 勲，友田泰行：透析療法 業務における人間工学的考察第一報一臨床工学技士 について一。阪透析会誌 $11: 231-235,1993$

2）黑澤 斌, 関 雄蔵, 二川 哲, 栗原 達, 黒澤 涁, 米虫節夫：人工藏器用糖加重炭酸型ドライタイプ透 析液の含量均一性と処方再現性。人工藏器 21 : 
963-966, 1992

3）斉藤久生, 秋葉 隆, 小山年勇, 阿部 薰, 星野正 信, 米虫節夫, 丸茂文昭: ドライケミカル低カルシ ウム透析液 (AKDD 25) の二次性副甲状腺機能九進 症患者における臨床評価. 人工臟器 $22: 30-33,1993$

4）太田和夫, 越川昭三, 黑川 清, 前川正信, 前田憲 志, 平沢由平, 鈴木利昭, 秋沢忠男, 深川雅史, 井 上聖士, 井原 元, 岡田洋一, 大野良興, 小野利彦, 大平整爾，衣笠光り子，小山年勇，黒澤 斌，鈴木 正司, 田中 寛, 鶴田良成, 鶴田 宏, 長沼信治, 成田真康, 星野正信, 堀口幸夫, 藤見 惺, 米虫節 夫：ドライケミカル透析液 AKDD (DD 25 および DD 30) の臨床効果 (II)。薬理と治療 $20 ： 695-724$, 1992

5）太田和夫，江良和雄，新井浩之，松崎竜児，峰島三 千男, 鈴木利昭, 仲里 聡, 江後友道: 多人数用重 炭酸透析液顆粒剂全自動溶解希釈装置の使用経験。
人工藏器 $21: 967-972,1992$

6) Tanaka H, Yoshimura I, Ohno Y, Maekawa M, Kishimoto $\mathrm{T}$ : Ergonomic studies of hemodialysis unit-in the case of clinical engineers-. Artif Organs $17: 456,1993$

7）吉村 勲, 友田泰行, 田中 寛: 透析療法業務の人 間工学的検討一その方法と液調製での展開一. 透析 会誌 26 (Suppl)：774，1993

8）田村小百合, 園田ク二子, 富田智美, 長谷川智子, 中野伸子, 川上百合子, 河合誠朗, 田中 寛, 大野 良興, 前川正信：透析療法業務における人間工学的 考察第二報一看護業務について一, 阪透析会誌 12 ： 55-59, 1994

9) Laura L, Matherly H, Lasater A : Implementing TQM in a Hospital. Quality Progress $25: 81-84$, 1992 